\title{
Hepatitis B Reactivation in Patients with Hematological and Solid Malignancies: A Retrospective Analysis of Single Center's Experience
}

\author{
Mustafa Yakut ${ }^{1}$, Zeynelabidin Demir ${ }^{2}$, Ahmet Siyar Ekinci ${ }^{3}$, M. Ali Kaplan³ ${ }^{3}$, $a t i m e ~$ Yakut $^{4}$ \\ ${ }^{1}$ Memorial Diyarbakir Hospital Gastroenterology Department, Diyarbakir, Turkey \\ ${ }^{2}$ Nursing Department, Batman University, Batman, Turkey \\ ${ }^{3}$ Memorial Diyarbakir Hospital Medical Oncology Department, Diyarbakir, Turkey \\ ${ }^{4}$ Memorial Diyarbakir Hospital Radiology Department, Diyarbakir, Turkey \\ Email:musyakut@gmail.com
}

How to cite this paper: Yakut, M., Demir, Z., Ekinci, A.S., Kaplan, M.A. and Yakut, F. (2019) Hepatitis B Reactivation in Patients with Hematological and Solid Malignancies: A Retrospective Analysis of Single Center's Experience. International Journal of Clinical Medicine, 10, 622-629.

https://doi.org/10.4236/ijcm.2019.1011051

Received: October 12, 2019

Accepted: November 23, 2019

Published: November 26, 2019

Copyright $\odot 2019$ by author(s) and Scientific Research Publishing Inc. This work is licensed under the Creative Commons Attribution International License (CC BY 4.0).

http://creativecommons.org/licenses/by/4.0/

(c) $\underset{\mathrm{EY}}{\mathrm{C}}$ Open Access

\begin{abstract}
Background: Hepatitis B reactivation might occur in patients with hematological and solid organ malignancies due to immunosuppressive effect of chemotherapy. Methods: Fourteen patients were evaluated retrospectively from their files to discuss the clinical manifestations, management, and avoiding of Hepatitis B reactivation within patients who receive immunosuppressive treatment. Results: These $14 \mathrm{HbsAg}$ positive patients were being followed up and treated via oncological immunosuppressive chemotherapy. The ages of the patients were between 25 and 72 . Seven of the patients were male, and the average follow up period for the patients was between 10 and 74 months. TV 0, $5 \mathrm{mg}$ was started for seven of the patients before the chemotherapy and TFV $245 \mathrm{mg}$ to one of the patients. LAM 100 was started for three patients whose basal HBV DNA was low. It has been analyzed that HBV DNA was negative in further observations. In follow up controls, we noticed HBV reactivation at two patients, LAM was given one of them and TFV was given the other one. One patient was applied allogeneic transplantation whose basal liver tests were normal and Hbsag was negative. Hepatitis B reactivation was detected after the first week of therapy. Conclusions: We offer testing in all patients undergoing cancer therapy for hepatitis B, HBsAg, core antibody (anti-HBc total), and anti-HBs before to start cancer therapy. Patients with higher risk of $\mathrm{HBV}$ reactivation require antiviral prophylaxis.
\end{abstract}

\section{Keywords}

Hepatitis B, Malignancies, Immunosuppression 


\section{Introduction}

Hepatitis $B$ reactivation might occur in patients with hematological and solid organ malignancies due to immunosuppressive effect of chemotherapy. Patients with a history of Hepatitis B who treated with immunosuppressive treatment are at risk for Hepatitis B reactivation and a serious hepatic attack, fulminant liver failure. This adverse condition can cause an interruption of chemotherapy, and can affect the success of primary solid cancer therapy. Several trials related to patients with solid tumors have suggested the efficacy of preventive anti-viral therapy. Many authors recommend testing all patients undergoing cancer treatment for hepatitis B in details such as hepatitis B surface antigen, hepatitis B core antibody, and hepatitis B surface antibody previous cancer therapy. Many authors recommend tenofovir or entecavir as preventive therapy, rather than lamivudine [1] [2] [3] [4].

HBV reactivations risk depends upon the kind of immunosuppressive drugs used. The risk of hepatitis $B$ reactivation is at a great high with the use of protocols that contain anti-CD20 monoclonal antibodies and high dose glucocorticoids. And also hematopoietic cell transplantation has a great high risk of hepatitis $B$ reactivation [1] [2] [3].

This study was performed in patients who underwent chemotherapy in South East Turkey where is an endemic location for hepatitis B virus, with an HBsAg prevalence of about $4 \%-6 \%$ [2]. Our article retrospectively analyzed to discuss the clinical manifestations, management, and avoiding of hepatitis $\mathrm{B}$ reactivation within patients who receive immunosuppressive treatment.

\section{Material Methods}

14 patients were evaluated retrospectively from their files in Diyarbakır Memorial Hospital Clinic of Gastroenterohepatology between September 2013 and September 2019. Oncological or hematological cancer patients with HbsAg positive and were exposed to immunsuppressive chemotherapy were selected for analysis. These $14 \mathrm{HbsAg}$ positive patients were being followed up and treated via oncological immunosuppressive chemotherapy.

\section{Results}

The ages of the patients were between 25 and 72, the average age was 51.5. Seven of the patients were male and the other 7 were female. The average follow up period for the patients were between 10 and 74 months.

HbsAg was positive in all of the patients. HbeAg and Anti-delta anticore were negative in all of the patients. Demographic and laboratory information of the patients are shown in Table 1 and Table 2. Three of the patients were being followed up previously as inactive carriers. Other patients were newly diagnosed; their HbsAg tests were appeared out to be positive in studies before chemotherapy. None of the patients had liver cirrhosis in clinic, laboratory and imaging studies and none of them had antiviral treatment history. Prophylactic antiviral 
M. Yakut et al.

Table 1. Patienst clinical and treatment characteristics.

\begin{tabular}{|c|c|c|c|c|c|c|c|}
\hline & Age & Sex & Liver Cirrhosis & Malignancy & Chemotherapy & $\begin{array}{l}\text { Antiviral } \\
\text { Therapy }\end{array}$ & $\begin{array}{c}\text { Follow up } \\
\text { (Month) }\end{array}$ \\
\hline 1. patient & 59 & $\mathrm{f}$ & no & Breast & TRANSTUZUMAB-PERTUZUMAB & ETV 0.5 & 16 \\
\hline 2. patient & 70 & $\mathrm{~m}$ & no & Gall Bladder & Gemcitabine + cddp & ETV 0.5 & 30 \\
\hline 3. patient & 44 & $\mathrm{f}$ & no & Breast & $\mathrm{AC}$ & ETV 0.5 & 39 \\
\hline 4. patient & 60 & $\mathrm{f}$ & no & Periton & Pacl + Carbo & ETV 0.5 & 27 (ex) \\
\hline 5. patient & 60 & $\mathrm{~m}$ & no & Prostate & $\begin{array}{c}\text { Zoladex }+ \text { docetaxel }+ \text { enzalutamid } \\
+ \text { zometa }\end{array}$ & ETV 0.5 & \\
\hline 6. patient & 55 & $\mathrm{~m}$ & no & Rectum & 5 FU, folfox-4 & ETV 0.5 & 39 \\
\hline 7. patient & 66 & $\mathrm{~m}$ & no & Lung & Gemcitabine & $\begin{array}{l}\text { Lam } 100 \mathrm{mg} \\
+ \text { TFV } 245 \mathrm{mg}\end{array}$ & $41(\mathrm{ex})$ \\
\hline 8. patient & 72 & $\mathrm{f}$ & no & $\begin{array}{c}\text { NHL } \\
\text { (Large cell) }\end{array}$ & $\begin{array}{c}5 \text { years before, } 6 \text { cure chop } \\
\text { Now R-ICE }\end{array}$ & $\begin{array}{l}\text { TFV } 245 \mathrm{mg}+ \\
\text { Lam } 100 \mathrm{mg}\end{array}$ & 72 \\
\hline 9. patient & 25 & $\mathrm{f}$ & no & $\begin{array}{l}\text { Giant cell tm of } \\
\text { bone }\end{array}$ & Proliakordexa & ETV $0.5 \mathrm{mg}$ & 40 \\
\hline 10. patient & 44 & $\mathrm{f}$ & no & NHL & BMT & ETV $1 \mathrm{mg}$ & 10 \\
\hline 11. patient & 46 & $\mathrm{f}$ & no & Breast & AC-Gemcitabine-Carboplatin-Doxataksel & TFV $245 \mathrm{mg}$ & 50 \\
\hline 12. patient & 70 & $\mathrm{~m}$ & no & Laryngeal-Lung & Gemcitabine-Daksotaksel-cisplatin & Lam $100 \mathrm{mg}$ & 48 \\
\hline 13. patient & 49 & $\mathrm{~m}$ & no & Testicular & CDDp-Carboplatin & Lam $100 \mathrm{mg}$ & 74 \\
\hline 14. patient & 61 & $\mathrm{~m}$ & no & Prostate & & Lam $100 \mathrm{mg}$ & 72 \\
\hline
\end{tabular}

Table 2. Patients baseline laboratory results.

\begin{tabular}{|c|c|c|c|c|c|c|c|c|c|}
\hline & $\begin{array}{c}\text { HBV DNA } \\
(\mathrm{IU} / \mathrm{mL})\end{array}$ & HBsAg & HBeAg & Anti-delta & PLT & INR & $\begin{array}{c}\text { AST } \\
(\mathrm{IU} / \mathrm{L})\end{array}$ & $\begin{array}{c}\text { ALT } \\
(\mathrm{IU} / \mathrm{L})\end{array}$ & $\begin{array}{c}\text { TBİL } \\
(\mathrm{mg} / \mathrm{dL})\end{array}$ \\
\hline 1. patient & 189.746 & positive & negative & negative & 220,000 & 1.1 & 28 & 38 & 0.11 \\
\hline 2. patient & 2539 & positive & negative & negative & 187,000 & 1.0 & 11 & 12 & 0.34 \\
\hline 3. patient & 0 & positive & negative & negative & 340,000 & 1.2 & 26 & 28 & 0.28 \\
\hline 4. patient & 1220 & positive & negative & negative & 365,000 & 1.0 & 33 & 55 & 0.33 \\
\hline 5. patient & 12 & positive & negative & negative & 293,000 & 1.0 & 31 & 42 & 0.18 \\
\hline 6. patient & 0 & positive & negative & negative & 420,000 & 0.9 & 17 & 3 & 0.24 \\
\hline 7. patient & 184,000 & positive & negative & negative & 178,000 & 1.2 & 269 & 289 & 0.89 \\
\hline 8. patient & $59,051.199$ & positive & negative & negative & 365,000 & 1.6 & 1350 & 1700 & 8.45 \\
\hline 10. patient & 1223.000 & positive & negative & negative & 229,000 & 1.7 & 2200 & 2120 & 11.2 \\
\hline 11. patient & 84 & positive & negative & negative & 397,000 & 1.1 & 11 & 11 & 0.64 \\
\hline 12. patient & 34 & positive & negative & negative & 178,000 & 1.2 & 23 & 27 & 0.21 \\
\hline 13. patient & 0 & positive & negative & negative & 196,000 & 0.9 & 34 & 29 & 0.44 \\
\hline 14. patiant & 0 & positive & negative & negative & 21,000 & 1.0 & 15 & 14 & 0.13 \\
\hline
\end{tabular}

treatment started before chemotherapy and continued until the sixth month after the end of the chemotherapy. The use of drugs was ended if liver tests were normal and HBV DNA was negative in the tests of the sixth months. 
ETV $0.5 \mathrm{mg}$ was started for seven of the patients before the chemotherapy and TFV $245 \mathrm{mg}$ to one of the patients. Apart from the first patient, HBV DNA values of these eight patients were negative or were less than $2000 \mathrm{IU}$. Basal HBV DNA value of the first patient was 189,746 IU. Liver tests of these eight patients were in normal values and HBV DNA values were negative. LAM 100 was started for three patients whose basal HBV DNA was low. It has been analyzed that HBV DNA was negative in 48, 72 and 74 month observations (Table 2).

Based on the normal liver tests LAM $100 \mathrm{mg}$ was started for patient number 7 whose previous HBV DNA was 200 IU. It has been observed that liver tests were elevated in seventeenth month. HBV DNA was 184,000 IU. TFV $245 \mathrm{mg}$ was added to the treatment. HBV DNA became negative in the following period.

Patient number eight had 6 doses of CHOP with the diagnosis of NHL five years ago. In that period, TFV $245 \mathrm{mg}$ was started. In January 2019, R-ICE treatment was applied because of nux. ALT: 700 Tbil 8.45 HBV DNA 59.051.199 IU values were detected at the third week of the treatment. $100 \mathrm{mg}$ LAM was added to TFV $245 \mathrm{mg}$ treatment. ALT Tbil values of the patient became normal. HBV DNA became negative in the second month.

Allogeneic transplantation was applied to patient number 10 because of Non-Hodgkin Lymphoma (NHL). Basal liver tests were normal and HbsAg were negative. However, Anti-HBc-IgG was not tested at the basal evaluation. The patient came to us with icteric sclera and skin after the first week of allogeneic transplantation therapy. The values of the patient were: Anti-HBc-IgG positive HBV DNA 1223.000 IU AST 2200 ALT 2120 Tbil 11.2. 1 mg ETV was started for the patient. Tbil was elevated to 21 and INR was elevated to 3, 2 in the following period. Patient was sent to liver transplantation center for close follow up. However, liver tests and bilirubin became normal with medical treatment. HBV DNA became negative.

\section{Discussion}

This study performed in South East Turkey where is an endemic location for hepatitis B virus, with an HBsAg prevalence of about 4\% - 6\% [2], Hepatitis B reactivation might occur in patients with malignancies because of immunosuppressive effect of chemotherapy. So that patients with a story of Hepatitis B who treated with immunosuppressive treatment are at risk for Hepatitis $B$ reactivation and a severe attack hepatitis B disease. This situation can conclude with elevated liver enzymes, fulminant liver failure [1] [4]. Furthermore, this negative situation (reactivation of hepatitis B) can cause an interruption of chemotherapy, delaying therapy of patient primary solid cancer. Although prophylactic antiviral therapy usage before chemotherapy has been recommended for patients with solid and hematological malignancies [5]-[9], many clinical studies related to patients with solid tumors have suggested the efficacy of preventive anti-viral therapy [10] [11]. In this article, we retrospectively analyzed naive 14 non-cirrhotic HBV positive patients with solid tumors. Our article review will discuss the clin- 
ical manifestations, management, and avoiding of Hepatitis B reactivation within patients who receive immunosuppressive treatment.

In one study, where hepatitis B prevalence similar to our region, Kim et al. examined on 178 patients with breast cancer while chemotherapy performed. 97\% of them were HBsAg negative, 35\% had abnormal hepatic function. Yet, only in $1 \%$ of patients acute hepatitis has been developed during chemotherapy [3] [12]. In Kim study, $60 \%$ of the HBsAg positive patients developed liver abnormalities, and also $33 \%$ of them had a progression to acute hepatitis. Furthermore, the incidence of hepatitis because of Hepatitis B reactivation was $21 \%$ of all cases. In this study they advocated that those findings are similar with other studies which documented a $24 \% \sim 28 \%$ incidence of Hepatitis B reactivation; even if the patients and chemotherapeutic protocols were different [3] [11] [13]. In another study that Kim et al. researched, lamivudine treatment was performed the patients when Hepatitis B reactivation was found. But, Lamivudine treatment didn't affect fast enough, indeed, chemotherapy treatment had to be delayed in $78 \%$ of these patients that was $16 \%$ of all 111 patients. They retrospectively analyzed of 2431 patients with early breast cancer. Within these patients, $111 \mathrm{HBsAg}$ positive female patients were accepted in their study. Thirty-seven patients (33.3\%) cultivated acute hepatitis, of that 23 (20.7\%) were associated with Hepatitis B reactivation. Those patients who diagnosed with hepatitis B reactivation were administered lamivudine at that case of hepatitis $B$ reactivation [3] [14] [15] [16]. However, opposite of Kim et al., some researchers have suggested prophylactic therapy via lamivudine in patients who had solid tumors [10] [11]. In one essay on breast cancer, it was found that the patients in a prophylactic lamivudine group had a lesser incidence of hepatitis $(12.9 \%$ vs. $59.0 \%)$, a decreased hepatitis B reactivation (6.5\% vs. $31.1 \%)$ and decreased cessation of chemotherapy ( $16.1 \%$ vs. $45.9 \%)$ according to a control group [17]. In our study, ETV 0, $5 \mathrm{mg}$ was started for seven of the patients before the chemotherapy and TFV $245 \mathrm{mg}$ to one of the patients. Almost all these 8 patients' HBV DNA level was less than 2000 IU. We obtained good results in follow up. LAM $100 \mathrm{mg}$ was started for three patients whose basal HBV DNA was low. It has been analyzed that HBV DNA was negative in follow-up results. In one patient who has normal basal liver tests, LAM $100 \mathrm{mg}$ was started whose previous HBV DNA was 200 IU. It has been observed that liver tests were elevated in seventeenth month. HBV DNA was 184,000 IU. TFV $245 \mathrm{mg}$ was added. HBV DNA became negative in the following period. On the other hand, another patient had 6 doses of CHOP with the diagnosis of NHL five years ago. In that period TFV $245 \mathrm{mg}$ was started. In the fifth year of TFV treatment, because of NHL nux, R-ICE treatment was applied. In this period due to hepatitis B flare, $100 \mathrm{mg}$ LAM was added to TFV $245 \mathrm{mg}$. HBV DNA became negative in the second month of the combination treatment.

Patients who receive anti-CD20 therapy and hematopoietic cell transplantation have a great high risk of hepatitis B reactivation, up to $20 \%$ [1]. In patients who are performed hematopoietic stem cell or solid organ transplantation are 
under the risk even in the patients who are HBsAg-negative. In some studies reported that HBsAg negative patients who are treated with allogeneic transplant have risk of hepatitis B reactivation [1] [18]-[28] allogeneic transplantation was applied to our one patient because of NHL. This patient's basal liver tests were normal and HbsAg were negative. However, Anti-HBcIgG was not evaluated at the basal evaluation. The patient came to us with hepatic flare in the first week after allogeneic transplantation. One mg ETV was started and at follow up, liver tests and bilirubin became normal range with medical treatment and HBV DNA became negative.

In conclusion, we offer testing in all patients undergoing cancer therapy for hepatitis B, HBsAg, core antibody (anti-HBc total), and anti-HBs before to start cancer therapy. Patients with higher risk of HBV reactivation require antiviral prophylaxis.

\section{Conflicts of Interest}

The authors declare no conflicts of interest regarding the publication of this paper.

\section{References}

[1] Lok, A., Bonis, P. and Esteban, R. (2017) Hepatitis B Virus Reactivation Associated with Immunosuppressive Therapy.

https://www.uptodate.com/contents/hepatitis-b-virus-reactivation-associated-with-i mmunosuppressive-therapy

[2] Aygen, B., Demir, A.M., Gümüş, M., Karabay, O., Kaymakoğlu, S., Köksal, A.Ş., Köksal, İ., Örmeci, N. and Tabak, F. (2018) Immunosuppressive Therapy and the Risk of Hepatitis B Reactivation: Consensus Report. Turkish Journal of Gastroenterology, 29, 259-269. https://doi.org/10.5152/tjg.2018.18263

[3] Kim, M.K., Ahn, J.H., Kim, S.B., Im, Y.S., Lee, S.I., Ahn, S.H., Son, B.H., Gong, G., Kim, H.H. and Kim, W.K. (2007) Hepatitis B Reactivation during Adjuvant Anthracycline-Based Chemotherapy in Patients with Breast Cancer: A Single Institution's Experience. The Korean Journal of Internal Medicine, 22, 237-243. https://doi.org/10.3904/kjim.2007.22.4.237

[4] Gupta, S., Govindarajan, S., Fong, T.L. and Redeker, A.G. (1990) Spontaneous Reactivation in Chronic Hepatitis B: Patterns and Natural History. Journal of Clinical Gastroenterology, 12, 562. https://doi.org/10.1097/00004836-199010000-00015

[5] Galbraith, R.M., Eddleston, A.L., Williams, R. and Zuckerman, A.J. (1975) Fulminant Hepatic Failure in Leukaemia and Choriocarcinoma Related to Withdrawal of Cytotoxic Drug Therapy. The Lancet, 2, 528-530. https://doi.org/10.1016/S0140-6736(75)90897-1

[6] Kumagai, K., Takagi, T., Nakamura, S., Sawada, U., Kura, Y., Kodama, F., Shimano, S., Kudoh, I., Nakamura, H., Sawada, K. and Ohnoshi, T. (1997) Hepatitis B Virus Carriers in the Treatment of Malignant Lymphoma: An Epidemiological Study in Japan. Annals of Oncology, 8, 107-109. https://doi.org/10.1093/annonc/8.suppl_1.S107

[7] Lau, G.K., He, M.L., Fong, D.Y., Bartholomeusz, A., Au, W.Y., Lie, A.K., Locarnini, S. and Liang, R. (2002) Preemptive Use of Lamivudine Reduces Hepatitis B Exacerbation after Allogeneic Hematopoietic Cell Transplantation. Hepatology, 36, 702-709. 
https://doi.org/10.1053/jhep.2002.35068

[8] Rossi, G., Pelizzari, A., Motta, M. and Puoti, M. (2001) Primary Prophylaxis with Lamivudine of Hepatitis B Virus Reactivation in Chronic HbsAg Carriers with Lymphoid Maligna Ncies Treated with Chemotherapy. British Journal of Haematology, 115, 58-62. https://doi.org/10.1046/j.1365-2141.2001.03099.x

[9] Liaw, Y.F., Leung, N., Guan, R., Lau, G.K., Merican, I., McCaughan, G., Gane, E., Kao, J.H. and Omata, M. (2005) Asian-Pacific Consensus Statement on the Management of Chronic Hepatitis B: A 2005 Update. Liver International, 25, 472-489. https://doi.org/10.1111/j.1478-3231.2005.01134.x

[10] Lau, G.K., Yiu, H.H., Fong, D.Y., Cheng, H.C., Au, W.Y., Lai, L.S., Cheung, M., Zhang, H.Y., Lie, A., Ngan, R. and Liang, R. (2003) Early Is Superior to Deferred Preemptive Lamivudine Therapy for Hepatitis B Patients Undergoing Chemotherapy. Gastroenterology, 125, 1742-1749. https://doi.org/10.1053/j.gastro.2003.09.026

[11] Yeo, W., Chan, P.K., Ho, W.M., Zee, B., Lam, K.C., Lei, K.I., Chan, A.T., Mok, T.S., Lee, J.J., Leung, T.W., Zhong, S. and Johnson, P.J. (2004) Lamivudine for the Prevention of Hepatitis B Virus Reactivation in Hepatitis B s-Antigen Seropositive Cancer Patients Undergoing Cytotoxic Chemotherapy. Journal of Clinical Oncology, 22, 927-934. https://doi.org/10.1200/JCO.2004.05.161

[12] Ahn, J.H., Kim, S.B., Yun, M.R., Lee, J.S., Kang, Y.K. and Kim, W.K. (2004) Alternative Therapy and Abnormal Liver Function during Adjuvant Chemotherapy in Breast Cancer Patients. Journal of Korean Medical Science, 19, 397-400. https://doi.org/10.3346/jkms.2004.19.3.397

[13] Yeo, W., Zee, B., Zhong, S., Chan, P.K., Wong, W.L., Ho, W.M., Lam, K.C. and Johnson, P.J. (2004) Comprehensive Analysis of Risk Factors Associating with Hepatitis B Virus (HBV) Reactivation in Cancer Patients Undergoing Cytotoxic Chemotherapy. British Journal of Cancer, 90, 1306-1311.

https://doi.org/10.1038/sj.bjc.6601699

[14] Wood, W.C., Muss, H.B., Solin, L.J. and Olopade, O.I. (2005) Infections in the Cancer Patient. In: DeVita, V.T., Hellman, S. and Rosenberg, S.A., Eds., Cancer. Principles \& Practice of Oncology, 7th Edition, Lippincott Williams and Wilkins, Philadelphia, 1446-1447.

[15] Levine, M. and Eisen, A. (2001) Anthracycline Adjuvant Chemotherapy: How Much Is Enough? Journal of Clinical Oncology, 19, 599-601.

https://doi.org/10.1200/JCO.2001.19.3.599

[16] Fumoleau, P., Kerbrat, P., Romestaing, P., Fargeot, P., Bremond, A., Namer, M., Schraub, S., Goudier, M.J., Mihura, J., Monnier, A., Clavere, P., Serin, D., Seffert, P., Pourny, C., Facchini, T., Jacquin, J.P., Sztermer, J.F., Datchary, J., Ramos, R. and Luporsi, E. (2003) Randomized Trial Comparing Six versus Three Cycles of Epirubicin-Based Adjuvant Chemotherapy in Premenopausal, Node-Positive Breast Cancer Patients: 10 Year Follow-Up Results of the French Adjuvant Study Group 01 Trial. Journal of Clinical Oncology, 21, 298-305. https://doi.org/10.1200/JCO.2003.04.148

[17] Yeo, W., Ho, W.M., Hui, P., Chan, P.K., Lam, K.C., Lee, J.J. and Johnson, P.J. (2004) Use of Lamivudine to Prevent Hepatitis B Virus Reactivation during Chemotherapy in Breast Cancer Patients. Breast Cancer Research and Treatment, 88, 209-221. https://doi.org/10.1007/s10549-004-0725-1

[18] Hammond, S.P., Borchelt, A.M., Ukomadu, C., et al. (2009) Hepatitis B Virus Reactivation Following Allogeneic Hematopoietic Stem Cell Transplantation. Biology of Blood and Marrow Transplantation, 15, 1049. 
https://doi.org/10.1016/j.bbmt.2009.05.001

[19] Tozun, N., Ozdogan, O., Cakaloglu, Y., et al. (2015) Seroprevalence of Hepatitis B and C Virus Infections and Risk Factors in Turkey: A Fieldwork TURHEP Study. Clinical Microbiology and Infection, 21, 1020-1026. https://doi.org/10.1016/j.cmi.2015.06.028

[20] Pei, S.N., Ma, M.C., Wang, M.C., et al. (2012) Analysis of Hepatitis B Surfaceantibody Titers in B Cell Lymphoma Patients after Rituximab Therapy. Annals of Hematology, 91, 1007-1012. https://doi.org/10.1007/s00277-012-1405-6

[21] Cho, Y., Yu, S.J., Cho, E.J., et al. (2016) High Titers of Anti-HBs Prevent Rituximab-Related Viral Reactivation in Resolved Hepatitis B Patient with Non-Hodgkin's Lymphoma. Journal of Medical Virology, 88, 1010-1017. https://doi.org/10.1002/jmv.24423

[22] Salpini, R., Colagrossi, L., Bellocchi, M.C., et al. (2015) Hepatitis B Surfaceantigen Genetic Elements Critical for Immune Escape Correlate with Hepatitis B Virus Reactivation upon Immunosuppression. Hepatology, 61, 823-833. https://doi.org/10.1002/hep.27604

[23] Gonzalez, S.A. and Perrillo, R.P. (2016) Hepatitis B Virus Reactivation in the Setting of Cancer Chemotherapy and Other Immunosuppressive Drug Therapy. Clinical Infectious Diseases, 62, 306-313. https://doi.org/10.1093/cid/ciw043

[24] Lee, Y.H., Bae, S.-C. and Song, G.G. (2013) Hepatitis B Virus (HBV) Reactivation in Rheumatic Patients with Hepatitis Core Antigen (HBV Occult Carriers) Undergoing Anti-Tumor Necrosis Factor Therapy. Clinical and Experimental Rheumatology, 31, 118-121.

[25] Reddy, N.M. and Savani, B.N. (2013) Hepatitis B Reactivation in Patients with Hematological Malignancies and Stem Cell Transplantation. Journal of Blood and Lymph, 4, 114.

[26] Shang, J., Wang, H., Sun, J., et al. (2016) A Comparison of Lamivudine Vsentecavir for Prophylaxis of Hepatitis B Virus Reactivation in Allogeneic Hematopoietic Stem Cell Transplantation Recipients: A Single-Institutional Experience. Bone Marrow Transplant, 51, 581-586. https://doi.org/10.1038/bmt.2015.328

[27] Paul, S., Dickstein, A., Saxena, A., et al. (2017) Role of Surface Antibody in Hepatitis B Reactivation in Patients with Resolved Infection and Hematologic Malignancy: A Meta-Analysis. Hepatology, 66, 379-388. https://doi.org/10.1002/hep.29082

[28] Hsu, C., Tsou, H.-H., Lin, S.-J., et al. (2014) Chemotherapy-Induced Hepatitis B Reactivation in Lymphoma Patients with Resolved HBV Infection: A Prospective Study. Hepatology, 59, 2092-2100. https://doi.org/10.1002/hep.26718 